\title{
Redetermination of the chromium position in ruby
}

\author{
By James W. McCauley * and G. V. GibBs ** \\ Materials Research Laboratory, The Pennsylvania State University \\ University Park, Pennsylvania
}

(Received 22 May 1971)

\begin{abstract}
Auszug
Eine nach der Ausgleichsmethode und auf Grund einer dreidimensionalen Sammlung von Intensitäten der Reflexe an einem Rubinkristall mit 5,2 Molprozent $\mathrm{Cr}_{2} \mathrm{O}_{3}$ durchgeführte Verfeinerung zeigt, daß $\mathrm{Cr}$ statistisch die Kationlage der Korundstruktur besetzt, jedoch daraus leicht, um $0,03 \AA$, auf das in der $c$-Richtung nächste Kation hin verschoben ist.
\end{abstract}

\section{Abstract}

Results of a least-squares refinement utilizing three-dimensional, singlecrystal, $\mathrm{x}$-ray-diffraction, intensity data from a ruby with $5.2 \mathrm{~mole} \% \mathrm{Cr}_{2} \mathrm{O}_{3}$ shows that $\mathrm{Cr}$ is disordered in the cation site of the corundum structure, but displaced (not significant) about $0.03 \AA$ toward the nearest cation along $c$.

Using $00 l$ single-crystal-diffractometer intensity data from a ruby, Moss and Newnham (1964) determined that $\mathrm{Cr}$ occupies the cation position in the corundum structure which is slightly different than $\mathrm{Al}$. Contrary to various theoretical calculations and spectroscopic evidence, their calculations showed that Cr was shifted $0.06 \AA$ along $c$ from the $\mathrm{Al}$ position and toward the nearest cation. The present study was undertaken to reinvestigate the structure of ruby using full threedimensional diffractometer data. The ruby studied was synthesized by BARKs (1966) and contained 5.2 mole $\%$ of $\mathrm{Cr}_{2} \mathrm{O}_{3}$. Its lattice parameters, $a=4.770(1)$ and $c=13.020(5) \AA$, are slightly larger than those obtained by Moss and Newnham (1964), $a=4.769$ and $c=13.018 \AA$, on a ruby with about 4 mole $\% \mathrm{Cr}_{2} \mathrm{O}_{3}$. MCCAULEY and

* Present address: Army Materials and Mechanics Research Center, Watertown, Massachusetts 02172.

** Present address: Virginia Polytechnic Institute and State University, Blacksburg, Virginia 24061. 
Gibis (1969) have already discussed a portion of this study with respect to the significance of weighting schemes in anisotropic leastsquares refinement. It was reported that $\mathrm{Cr}$ is disordered in the cation site of the corundum structure. However, further investigation utilizing the Moss and Newnhay (1964) technique indicates that $\mathrm{Cr}$ occupies a position which is slightly different than Al. Standard least-squares procedures had to be slightly modified in order to use the Moss and Newrinam (1964) method. Because of the physically unrealistic variation of the temperature factors of $\mathrm{Al}$ and $\mathrm{Cr}$ and high correlation between the $z$ positional parameter of $\mathrm{Al}$ and $\mathrm{Cr}$, the temperature factors were not varied and the three positional parameters were varied successively until convergence obtained. The resulting values are as follows:

\begin{tabular}{c|c|c|c|c}
\hline \multirow{2}{*}{} & \multicolumn{2}{|c|}{ This work } & \multicolumn{2}{c}{ Moss and NEWNHAM } \\
\cline { 2 - 5 } & value & $\sigma$ & value & $\sigma$ \\
\hline$x$ & 0.3049 & 0.0009 & 0.306 & - \\
$z_{\mathrm{Al}}$ & 0.3518 & 0.0002 & 0.352 & - \\
$z_{\mathrm{Cr}}$ & 0.3495 & 0.002 & 0.347 & - \\
weighted $R$ & $3.5 \%$ & & $1.8 \%$ &
\end{tabular}

The $\mathrm{Cr}$ positional parameter was first arbitrarily shifted to a larger value than $z_{\mathrm{Al}}$ and then to a small value; both refined to the value listed above. In an anisotropic temperature-factor refinement using only one cation position the following parameters were obtained: $x_{\mathrm{O}}=0.3068(5), z_{(\mathrm{Al}, \mathrm{Cr})}=0.3519(1)$, and the weighted $R=2.6 \%$. The latter value cannot be meaningfully compared to the $R$ value obtained using the two-position cation refinement because of the variability in the two techniques.

It is interesting to note that the parameters obtained in this study are not statistically different from those obtained by Moss and Newnham. The Cr position, however, is only about one $\sigma$ different from the Al position, and therefore not significantly different. The data reaffirm that the movement is toward the nearest cation and not away from it. Further, notice that the oxygen position is slightly different than the one-cation-position refinement result. The movement is such that both the $\mathrm{O}-\mathrm{O}$ distance in the shared face and the $\mathrm{M}-\mathrm{O}$ distance to the shared face are shorted. Electron-density and difference-Fourier maps did not resolve the small shifts. SAaLFELD 
(1964), however, did see small changes in Fourier maps that he obtained for $\mathrm{Al}_{2} \mathrm{O}_{3},(\mathrm{Al}, \mathrm{Cr})_{2} \mathrm{O}_{3}$ and $\mathrm{Cr}_{2} \mathrm{O}_{3}$.

Finally, the interpretation of the results is further complicated by the observation that a number of the high-order reflections from the ruby exhibited slight peak splitting. LINZ and NEwNHAM (1961) have also noted that high-order peaks from ruby powders of intermediate composition exhibt marked broadening. These problems require further detailed study on other rubies of higher $\mathrm{Cr}$ content before they can be resolved satisfactorily.

We would like to thank Professor R. E. Newnham for many helpful suggestions. This work was supported by ARPA grants SD-132 and DA-49-083 OSA-3140.

\section{References}

R. E. BARKS (1966), Flux growth of single crystal $\mathrm{R}_{2} \mathrm{O}_{3}$ oxides with the corundum structure. Ph. D. thesis in geochemistry, The Pennsylvania State University.

A. Linz, JR. and R. E. NewnhaM (1961), Ultraviolet absorption spectra in ruby, Physic. Review 128, 500-501.

J. W. MoCAdLex and G. V. GrbBs (1969), Significance of weighting schemes in an anisotropic least squares refinement of ruby. In Molecular dynamics and structure of solids (R. S. CARTER and J.J.Rush, eds.), N.B.S. Special Publication 301, 277-282.

S. C. Moss and R. E. Newnham (1964), The chromium position in ruby. Z. Kristallogr. 120, 359-363.

H. SAALFELD (1964), Strukturuntersuchungen im System $\mathrm{Al}_{2} \mathrm{O}_{3}-\mathrm{Cr}_{2} \mathrm{O}_{3}$. Z. Kristallogr. 120, 342-348. 